\title{
Paradoxical progression of intracranial tuberculomas and anterior cerebral artery infarction
}

Figure Initial and follow-up MRI examinations


Initial MRI shows acute infarction in the cingulate cortex and corpus callosum on FLAIR sequence (A) and several gadolinium-enhancing nodular lesions in the cerebellum and cerebrum ( $B$ and $C$ ). MR angiography shows mild narrowing of the proximal anterior cerebral arteries (D). Follow-up MRI performed 40 days later shows slightly increased size of infarction (E) and markedly increased number of enhancing lesions throughout the whole brain ( $F$ and G). MR angiography demonstrates severe diffuse narrowing of the anterior cerebral arteries $(\mathrm{H})$.

An immunocompetent 52-year-old woman presented with subacute onset of headache, vomiting, and mental deterioration after 3 weeks' history of fever, cough, and dyspnea. Diagnostic workups confirmed pulmonary miliary tuberculosis, multiple intracranial tuberculomas, and tuberculous meningovasculitis causing cerebral infarction (figure, A-D). Treatments with antituberculous medications (oral isoniazid $300 \mathrm{mg} /$ day, rifampin $450 \mathrm{mg} /$ day, pyrazinamide $1,000 \mathrm{mg} /$ day, IM streptomycin $750 \mathrm{mg} /$ day $)$ and IV dexamethasone $(16 \mathrm{mg} /$ day) were commenced. Two weeks later, she regained alertness but showed akinetic mutism and urinary incontinence. Follow-up MRI showed slightly increased size of infarction, markedly increased number of tuberculomas, and worsening of cerebral arteritis (figure, $\mathrm{E}-\mathrm{H}$ ).

CNS arteritis leading to cerebral infarction is the most serious complication of tuberculous meningitis. Paradoxical development or progression of intracranial tuberculomas during the course of treatment has been recognized previously. ${ }^{1}$ Our main concern is that the serial MRI examinations of our patient showed a paradoxical progression of tuberculomas along with an aggravation of anterior cerebral artery vasculitis, despite the appropriate treatments with antituberculous medications and dexamethasone. ${ }^{2}$

Sung Ik Lee, MD, Jeong Hyun Park, MD, Ji Hyun Kim, MD, Seoul, Korea

Supported by a grant from Wonkwang University in 2008.

Disclosure: The authors report no disclosures.

Address correspondence and reprint requests to Dr. Kim, Department of Neurology, Korea University Medical Center, Korea University College of Medicine, 80 Guro-Dong, Guro-Ku, Seoul, 152-703, Republic of Korea; jhkim.merrf@gmail.com

1. Nicolls DJ, King M, Holland D, Bala J, del Rio C. Intracranial tuberculomas developing while on therapy for pulmonary tuberculosis. Lancet Infect Dis 2005;5:795-801.

2. Thwaites GE, Nguyen DB, Nguyen HD, et al. Dexamethasone for the treatment of tuberculous meningitis in adolescents and adults. N Engl J Med 2004;351:1741-1751. 


\section{Neurology}

\section{Paradoxical progression of intracranial tuberculomas and anterior cerebral artery infarction}

Sung Ik Lee, Jeong Hyun Park and Ji Hyun Kim

Neurology 2008;71;68

DOI 10.1212/01.wnl.0000316309.86367.3e

This information is current as of June 30, 2008

\section{Updated Information \& Services}

References

Citations

Subspecialty Collections

Permissions \& Licensing

Reprints including high resolution figures, can be found at: http://n.neurology.org/content/71/1/68.full

This article cites 2 articles, 0 of which you can access for free at: http://n.neurology.org/content/71/1/68.full\#ref-list-1

This article has been cited by 1 HighWire-hosted articles: http://n.neurology.org/content/71/1/68.full\#\#otherarticles

This article, along with others on similar topics, appears in the following collection(s):

\section{Bacterial infections}

http://n.neurology.org/cgi/collection/bacterial_infections

Meningitis

http://n.neurology.org/cgi/collection/meningitis

MRI

http://n.neurology.org/cgi/collection/mri

Other cerebrovascular disease/ Stroke

http://n.neurology.org/cgi/collection/other_cerebrovascular_disease_st roke

Information about reproducing this article in parts (figures,tables) or in its entirety can be found online at:

http://www.neurology.org/about/about_the_journal\#permissions

Information about ordering reprints can be found online:

http://n.neurology.org/subscribers/advertise

Neurology ${ }^{\circledR}$ is the official journal of the American Academy of Neurology. Published continuously since 1951, it is now a weekly with 48 issues per year. Copyright . All rights reserved. Print ISSN: 0028-3878. Online ISSN: 1526-632X.



